\title{
ELECTRIC VEHICLE CONVERSION: OPTIMISATION OF PARAMETERS IN THE DESIGN PROCESS
}

\author{
Mirko Gordić, Dragan Stamenković, Vladimir Popović, Slavko Muždeka, Aleksandar Mićović
}

Preliminary communication

One of the directions for making cleaner and more economic vehicles is to adopt electric vehicle concept. The paper shows current design concepts for electric vehicles worldwide, as well as current sources for supplying vehicles with electric energy. It describes a conversion of one vehicle so that it can be powered by electric motor. The results of tractive and dynamic characteristics calculation and vehicle stability simulation, before and after the conversion, are shown. Obtained results and influential factors are analysed so they can be optimised in order to influence the final characteristics of the converted vehicle. The conclusion is that the complete optimisation process should be performed before the beginning of vehicle conversion in order to avoid undesirable effects, i.e. undesirable characteristics of converted vehicle and high conversion costs.

Keywords: conversion; electric vehicle; vehicle dynamics

Prepravak u električno vozilo: optimizacija parametara u procesu konstruiranja

Prethodno priopćenje

Jedan od pravaca ka stvaranju čistijih i ekonomičnijih vozila jeste prihvatanje koncepta električnog vozila. Rad predstavlja suvremene koncepte konstrukcije električnih vozila širom svijeta, kao i načine snabdjevanja vozila energijom. Opisan je prepravak vozila kako bi ga se moglo pogoniti elektromotorom. Prikazani su rezultati vučno-dinamičkog proračuna i simulacije stabilnosti prije i poslije prepravka. Analizirani su dobiveni rezultati i utjecajni čimbenici radi optimiziranja u cilju utjecaja na karakteristike prepravljenog vozila. Zaključeno je da je proces optimizacije neophodno provesti prije početka prepravka kako bi se izbjegle neželjene posljedice, tj. neželjene karakteristike prepravljenog vozila i visoki troškovi prepravka.

Ključne riječi: dinamika vozila; električno vozilo; prepravak

\section{Introduction}

At the mention of global warming, the first thing that comes to mind is an increasing number of vehicles in traffic, as well as exhaust gases these vehicles emit. Analyses show that, from 1880 to 2012, average temperature on the surface of the Earth has increased by $0,85^{\circ} \mathrm{C}[1]$, and it is anticipated that by the end of the $21^{\text {st }}$ century this value will reach $3,7^{\circ} \mathrm{C}$ [2]. In the meantime, concentration of carbon dioxide $\left(\mathrm{CO}_{2}\right)$ in the air has increased by $40 \%$ compared to preindustrial period [2]. It is expected that climate changes will have direct effect on flora and fauna of the planet [3].

It is estimated that $26,33 \%$ of greenhouse gases emitted in 2011 in the US are caused by transportation (41,2\% of which by passengers cars) [4].

European Environment Agency estimates that $24 \%$ of greenhouse gases emitted in European Union are caused by transportation, with road transportation taking part with $19 \%$ in total greenhouse gas emission [5].

At the Paris Climate Change Conference held in November 2015, the parties adopted the agreement on limiting the global warming. The climate agreement anticipates that, by the end of the century, the increase in global average temperatures will be limited below $2{ }^{\circ} \mathrm{C}$ compared to preindustrial period [6].

There is a long-time tendency within automotive industry to build vehicles with as low $\mathrm{CO}_{2}$ emission as possible. Large vehicle manufacturers make enormous investments in the development of hybrid drive vehicles, fuel cell powered vehicles and electric vehicles.

This paper describes a modification procedure for a specific vehicle and a comparative calculation of tractive and dynamic characteristics. In the conclusion, the importance of shown analyses is emphasised from the aspect of optimising vehicle parameters when making decisions regarding production, i.e. conversion into a completely electric vehicle.

\section{Electric vehicle drive}

One or more electric motors are used to propel an electric vehicle. Electric motors can significantly differ in construction, working principle, mass and dimensions which are all parameters that need to be considered in the design process. However, the types of electric motors used in vehicles will not be discussed in this paper, but only the concepts for their installation.

Over the time, four basic concepts have become dominant in terms of the number and position of electric motors $[7,8]$ :

- Centrally positioned motor which transmits its power and torque through reduction drives, differentials and drive shafts to the wheels;

- Wheel-hub drive or in-wheel drive is a concept where a motor without the reduction drive is placed directly on the driven wheel; There are no losses in power transmission system here, but since there is no reduction drive, the motor works most of the time in insufficiently efficient mode with low RPM and high torque;

- Wheel-hub with reduction drive - this solution eliminates the issue of insufficient efficiency by installing additional reduction drive; There are also no losses in power transmission system in this case; However, the main disadvantage of this and the previous concept is the increase in vehicle unsprung mass which affects vehicle manoeuvrability and increases vibration; 
- Close-wheel drive is a drive where motor and reduction drive are integrated into a single assembly. However, unlike previous two concepts, power and torque are transmitted to the driven wheels through drive shafts; This way, there is no increase in vehicle unsprung mass; This concept was applied to Mercedes-Benz SLS AMG E-CELL vehicle.

If we add gearboxes to these four concepts, we could generally make a total of six typical configurations that could be divided into two groups, depending on the number of installed electric motors:

- One-motor drive:

- Motor, gearbox, differential, drive shafts, wheels;

- Motor, constant gear ratio reduction drive, differential, drive shafts, wheels;

- Motor and reduction drive integrated into single assembly, differential, drive shafts, wheels.

- Two-motor drive:

- Motor and reduction drive integrated into a single assembly, drive shafts, wheels, no differential;

- Electric motor with integrated reduction drive in wheel (so-called wheel-hub with reduction drive);

- Wheel-hub (in-wheel).

The vehicle analysed in this paper was modified by installing one electric motor and it has a gearbox, a differential and a drive shaft.

\section{Electric energy supply}

The previous part of the paper presented basic concepts of electric vehicle design regarding their drive. However, in order to use these vehicles, we need to provide them with such power sources that will enable easy transport, low price and satisfactory vehicle autonomy. That is, in fact, the biggest problem the electric vehicle manufacturers are faced with.

Nowadays, we expect the best results from the development of the following three basic concepts for supplying the electric motors with energy $[9 \div 12]$ :

- Battery electric vehicles (BEV) - they have a set of rechargeable batteries permanently installed onto the vehicle;

- Hybrid electric vehicles (HEV);

- Fuel cell electric vehicles (FCEV).

For vehicles powered by batteries (BEV) and fuel cells (FCEV), it is necessary to provide completely new infrastructure. Hybrid electric vehicles (HEV) can use existing infrastructure since they use internal combustion engine as a power source.

BEVs and FCEVs are characterised by zero exhaust emission, independence on petroleum products and high efficiency of supplied energy. On the other hand, HEVs depend on petroleum products and are characterised by low emission and high economy compared to the vehicles powered by internal combustion engines, as well as by satisfactory autonomy.

Main issues to be solved to facilitate the usage of BEVs are high initial cost, relatively small range, choice of batteries and their management, as well as charging infrastructure. However, the advantages of BEVs outweigh the problems mentioned.

For hybrid vehicles, the issues are dependence on petroleum derivatives, complex systems, energy source management and dependence on driving style.

There is a small number of FCEVs on the market, and these vehicles are usually built in small series (Honda FCX Clarity, Toyota Mirai, Mercedes-Benz F-CELL...). Basic issues are manufacturing, hydrogen storage and transport, high costs and infrastructure.

The vehicle analysed in this paper uses lithium-ion batteries as energy source (BEV).

\section{Description of the conversion}

The converted vehicle is FIAT PUNTO MkII 1.9 JTD, production year 2001. Schematic view of the converted vehicle is shown in Fig. 1.

Technical characteristics of the original vehicle:

- Vehicle category: $\mathrm{M}_{1}$

- Maximum engine power: 59 kW@3000 RPM

- Maximum engine torque: 196 Nm@1500 RPM

- Engine displacement: $1910 \mathrm{~cm}^{3}$

- Working principle: Compression engine

- Vehicle mass in running order: $1170 \mathrm{~kg}$

- Number of seats: 5

Technical characteristics of the converted vehicle:

- Vehicle category: $\mathrm{N}_{1}$

- Maximum engine power: 41,51 kW@3700 RPM

- Maximum engine torque: 128 Nm@1500 RPM

- Working principle: Electric motor

- Vehicle mass in running order: $1215 \mathrm{~kg}$

- Number of seats: 2

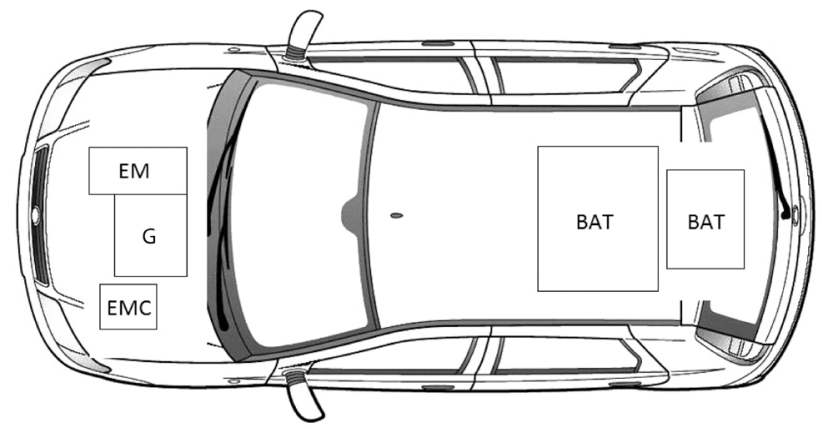

Figure 1 Schematic view of the positions of the elements installed onto the converted vehicle (EM - electric motor, EMC - electric motor controller, G - gearbox, BAT - batteries)

The choice of the electric motor and the batteries was made in such a way as to result in the lowest possible difference in the mass of uninstalled and newly installed elements, while retaining (as much as possible) the original mass distribution between the axles. This could not be done entirely, due to the fact that the mass of the batteries is substantially higher than the mass of the full fuel tank.

Lithium iron phosphate (LiFePO4) batteries were chosen for storing the energy needed. Batteries of this type do not emit fluids or gases during normal operation. Most important characteristics of the batteries installed are shown in Tab. 1 [13]. 
An asynchronous three-phase electric motor with frequency regulation is chosen to propel the vehicle. Weight of the motor is $45 \mathrm{~kg}$. The characteristics of the motor, including the torque and power diagram, were obtained from the manufacturer [14].

Table 1 Specification of the batteries used

\begin{tabular}{|l|c|}
\hline Mass (kg) & 3,25 \\
\hline Cell dimensions (mm) & $220 \times 142 \times 67$ \\
\hline Nominal capacity at 33,3 A (Ah) & 100 \\
\hline Nominal voltage (V) & 3,2 \\
\hline Charging cut-off voltage (V) & $3,8 \pm 0,05$ \\
\hline Discharging cut-off voltage (V) & $2,8 \pm 0,05$ \\
\hline Nominal charging current (A) & 33,3 \\
\hline Nominal discharging current $(\mathrm{A})$ & 33,3 \\
\hline Max continuous charging current $(\mathrm{A})$ & 300 \\
\hline Max continuous discharging current $(\mathrm{A})$ & 300 \\
\hline Max discharging current $(<10 \mathrm{~s})(\mathrm{A})$ & 500 \\
\hline
\end{tabular}

The following parts and equipment used to power the vehicle by internal combustion engine (ICE) were removed from the vehicle:

- Engine with auxiliary units;

- Engine electric wiring;

- Exhaust system;

- Fuel tank and supply system.

Additionally, in order to place the batteries and change the vehicle category, the rear bench with three seats was removed, as well as its accompanying equipment.

The electric motor (EM) was placed into the vehicle instead of the factory-fitted ICE. For the purpose of mounting the motor and connecting it to the gearbox, an intermediate plate was built. Purpose-built mounting brackets ensured that suspension points of installed electric motor correspond to the suspension points of ICE. Motor control unit and battery charger were fixed above the motor using special mounting bracket.

An additional vacuum pump with electric valve was fitted to ensure a servo brake effect. The electric motor and the controller are cooled by a coolant flowing through two independent closed systems. Each system has its own cooler.

In the middle and the rear part of the vehicle, in place of spare wheel and fuel tank, a part of bodywork floor was cut out and two purpose-built 1,25 mm thick sheet steel boxes were fitted and welded securely to the vehicle floor. The boxes were reinforced so they could handle batteries weighing $195 \mathrm{~kg}$ (60 cells with the individual weight of $3,25 \mathrm{~kg}$ ). The cells were placed in two serially connected groups, with the output voltage of $60 \times 3,5 \mathrm{~V}=210 \mathrm{~V}$. When installing the battery boxes, a special care was taken so that bodywork torsional rigidity could remain intact. Therefore, box edges were additionally reinforced so they could handle deformations during the vehicle movement. The interior of the battery boxes was covered with hard rubber acting as an electric insulator, as well as vibration absorber and thermal insulator to avoid a decrease in battery capacity at low temperatures.

Batteries are serially connected using special plates and screws. There is a threaded opening in the middle of each plate where, by using a screw, a control cable for Battery management system (BMS) can be connected.

BMS [15] is connected, via charger, to the battery charging socket (which was installed instead of fuel filler neck). This system controls the charging of each cell separately. The batteries are connected to the motor using three conductors with the cross-section of $50 \mathrm{~mm}^{2}$.

Carrying capacity of the batteries mounting elements was calculated using the finite element method. For each battery box and for each cover, an analysis was conducted for the case of $15 \mathrm{~g}$ side impact, $20 \mathrm{~g}$ front impact, $10 \mathrm{~g}$ rear impact and $10 \mathrm{~g}$ vertical acceleration. All calculations were made in SolidWorks software package. Deformations of bigger box are shown in Fig. 2, 3, 4 and 5 .

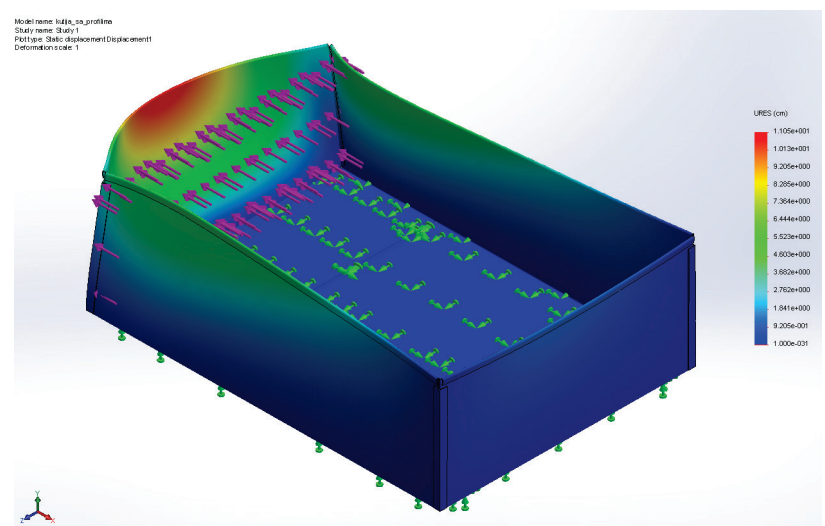

Figure 2 Deformation of bigger box in case of $15 \mathrm{~g}$ side impact (max deformation $110 \mathrm{~mm}$ )

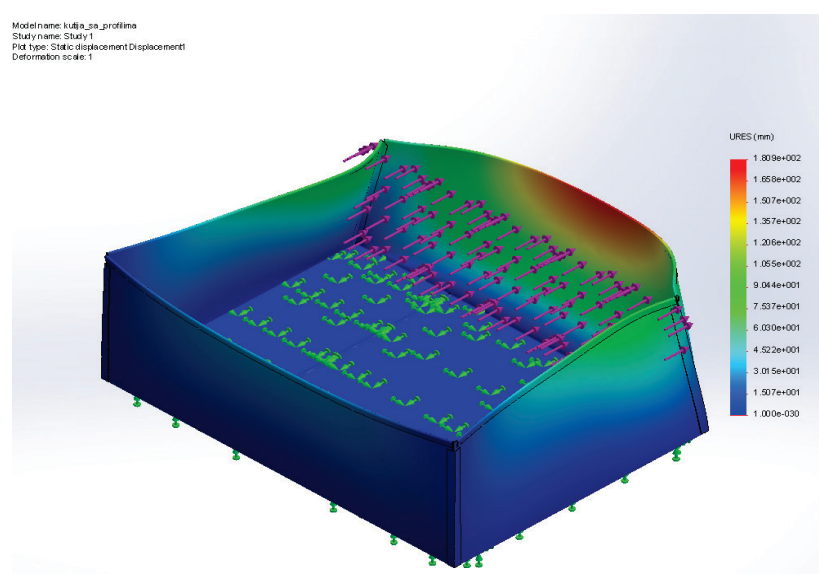

Figure 3 Deformation of bigger box in case of $20 \mathrm{~g}$ front impact (max deformation $180 \mathrm{~mm}$ )

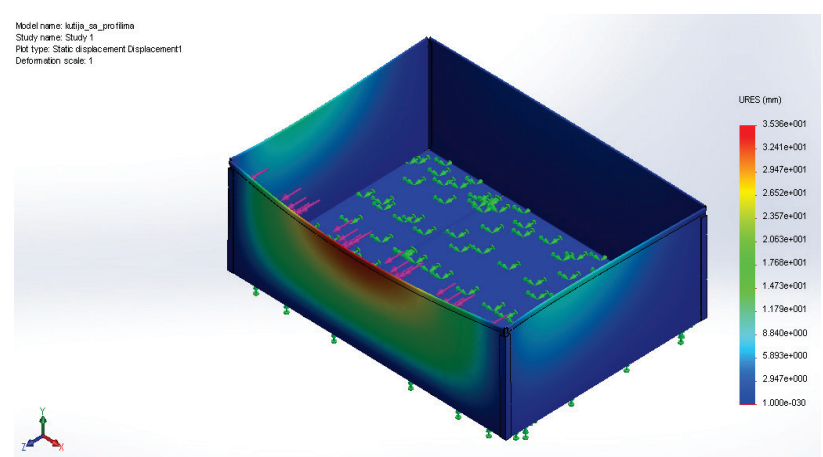

Figure 4 Deformation of bigger box in case of $10 \mathrm{~g}$ rear impact (max deformation $35 \mathrm{~mm}$ ) 


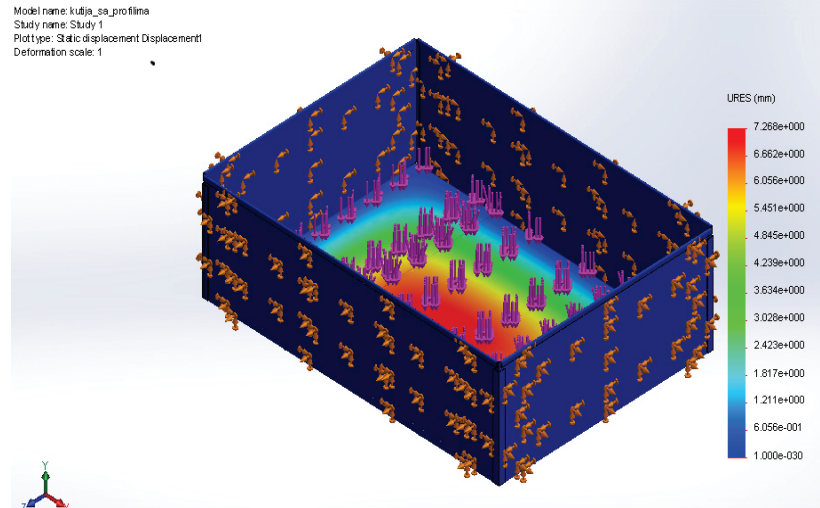

Figure 5 Deformation of bigger box in case of $10 \mathrm{~g}$ vertical acceleration (max deformation $73 \mathrm{~mm}$ )

\section{Comparison of tractive and dynamic vehicle} characteristics before and after conversion

\subsection{Adopted values}

Rolling resistance coefficient for speeds higher than $50 \mathrm{~km} / \mathrm{h}$ was calculated using the following equation [16]:

$$
f=0,0165 \cdot[1+0,00625 \cdot(v-50)],
$$

where $v$ is in $\mathrm{km} / \mathrm{h}$.

Adhesion coefficient for dry asphalt was adopted to be $\varphi=0,75$ [16], while transmission efficiency coefficient was adopted as $\eta_{p}=0,9$ [16]. Drag coefficient and frontal area were estimated as $c_{x}=0,3$ and $A=1,95 \mathrm{~m}^{2}$, respectively.

Torque and power diagram for ICE and EM is shown in Fig. 6 (data obtained from the manufacturers). More data needed for calculation are shown in Tab. 2.

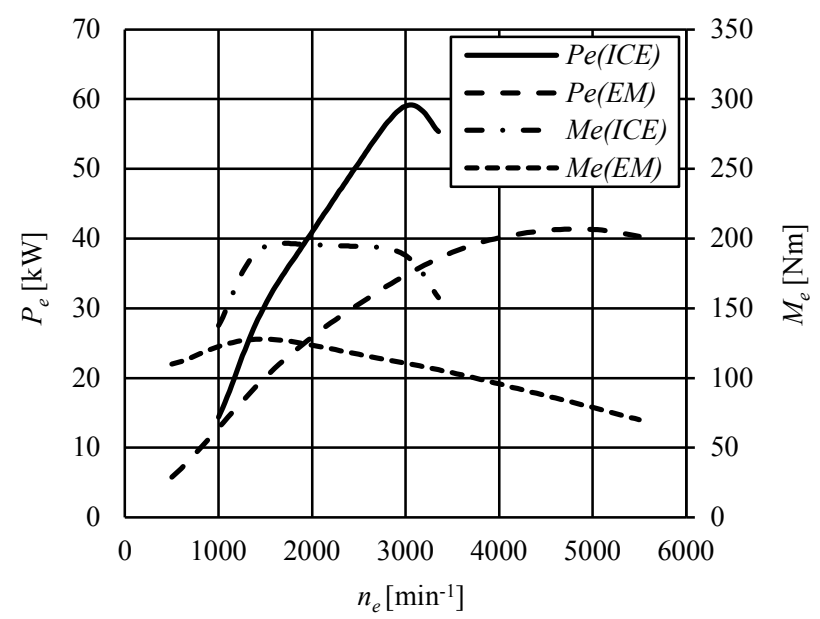

Figure 6 Torque and power diagram for ICE and EM

\subsection{Mass and geometrical parameters}

Vehicle mass and geometrical parameters before and after the conversion are given in Tab. 3 .

\subsection{Comparison of tractive and dynamic characteristics}

Calculation of tractive and dynamic characteristics of the vehicle before and after the conversion was made on the basis of adopted values, analysis of resistance forces and the power available, installed gearbox and adhesion limit, taking into account vehicle behaviour.

Table 2 Gearbox ratios and tyre rolling radius

\begin{tabular}{|l|l|c|}
\hline \multirow{4}{*}{ Gear ratios $(-)$} & $1^{\text {st }}$ gear $i_{\mathrm{I}}$ & 3,909 \\
\cline { 2 - 3 } & $2^{\text {nd }}$ gear $i_{\mathrm{II}}$ & 2,238 \\
\cline { 2 - 3 } & $3^{\text {rd }}$ gear $i_{\mathrm{III}}$ & 1,444 \\
\cline { 2 - 3 } & $4^{\text {th }}$ gear $i_{\mathrm{IV}}$ & 1,029 \\
\cline { 2 - 3 } & $5^{\text {th }}$ gear $i_{\mathrm{V}}$ & 0,767 \\
\cline { 2 - 3 } & final drive $i_{\mathrm{O}}$ & 2,85 \\
\hline \multicolumn{2}{|c|}{ Tyre rolling radius $r_{d}(\mathrm{~m})$} & 0,29 \\
\hline
\end{tabular}

Table 3 Mass and geometrical parameters before and after the conversion

\begin{tabular}{|l|c|c|}
\hline \multicolumn{1}{|c|}{ Value } & Before & After \\
\hline Mass in running order (kg) & 1170 & 1215 \\
\hline Maximum permissible mass (kg) & 1565 & 1565 \\
\hline $\begin{array}{l}\text { Axle loads in running order (kg) } \\
\text { front }\end{array}$ & 790 & 660 \\
$\quad$ rear & 380 & 555 \\
\hline $\begin{array}{l}\text { Maximum permissible axle loads (kg) } \\
\text { front } \\
\text { rear }\end{array}$ & 900 & 900 \\
\hline Centre of gravity height (m) & 750 & 750 \\
\hline Longitudinal distance between the front axle \\
wheel centreline and centre of gravity (m) & 0,79 & 0,58 \\
\hline
\end{tabular}

Maximum vehicle speed value is determined by the power balance. Vehicle speed in $i^{\text {th }}$ gear can be calculated as

$v_{i}=\frac{\omega_{e} \cdot r_{d}}{i_{g b i} \cdot i_{o}}$,

while resistance power is calculates as

$$
P=G \cdot f \cdot v+\frac{1}{2} c_{x} \cdot \rho \cdot A \cdot v^{3}
$$

Fig.7 shows how maximum vehicle speeds before and after modification were determined. The graph shows available power to the drive wheel as a function of vehicle speed before and after the modification. The diagram of power needed to overcome the resistance is also shown. Maximum speeds are defined by the points in which diagrams of vehicle power and of power for overcoming the resistance intersect. This diagram shows that the maximum vehicle speed after the modification is lower than the maximum vehicle speed before the modification. Maximum vehicle speed can be achieved in $3^{\text {rd }}$ gear. This result is logical considering the fact that the installed electric motor has lower power output than the factoryfitted internal combustion engine. The obtained result was verified by testing the vehicle on roller dynamometers. For the purpose of daily usage of the vehicle, better safety and protection of installed components (especially batteries), maximum vehicle speed was limited to 90 $\mathrm{km} / \mathrm{h}$ by reprogramming the controller.

A power balance before and after the conversion shows that, beside the fact that the maximum power of $\mathrm{EM}$ is lower than that of ICE, additional problem is that the power is achieved with EM at higher RPM values. 


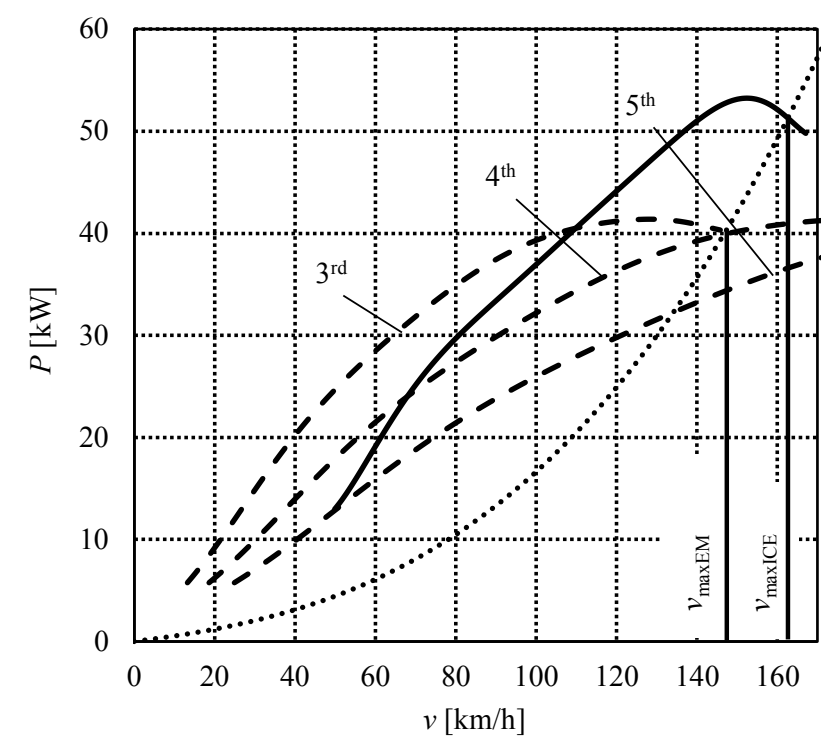

Figure 7 Maximum vehicle speed before $\left(v_{\operatorname{maxICE}}\right)$ and after $\left(v_{\operatorname{maxEM}}\right)$ the conversion (solid line denotes ICE power on wheels, dashed lines denote

EM power on wheels, while dotted line denotes resistance power)

Traction force in $i^{\text {th }}$ gear $F_{o i}$ is calculated as

$$
F_{o i}=\frac{M_{e} \cdot \eta_{p} \cdot i_{g b i} \cdot i_{o}}{r_{d}}
$$

where: $M_{e}-$ output torque, $\eta_{p}-$ transmission efficiency coefficient, $i_{g b i}-$ gearbox ratio in $i^{\text {th }}$ gear, $i_{o}-$ final drive gear ratio, $r_{d}$-tyre rolling radius.

Fig. 8 shows how tractive force was changed with the conversion. It can be spotted that force values are lower than before the conversion.

Vehicle acceleration can be calculated using the following equation:

$a_{i}=\left(\frac{F_{o i}-R_{W}}{G}-f\right) \frac{g}{\delta}$,

where: $a_{i}-$ acceleration in $i^{\text {th }}$ gear, $R_{W}-$ air drag resistance, $\delta$ - rotating mass inertia coefficient.

Changes in acceleration diagram caused by the conversion are shown in Fig. 9. As with the previous diagram, a reduction after the conversion is noticeable. It can be noticed that acceleration times are prolonged with the conversion. Also, because of the bigger RPM range, number of gear changes needed is reduced.

Acceleration time is calculated using the following equation:

$t=\int_{0}^{v} \frac{1}{a} d v$.

Acceleration times before and after the conversion are shown in Fig. 10. Acceleration time values are higher after the conversion. Having in mind the speed limit for the converted vehicle $(90 \mathrm{~km} / \mathrm{h})$, it can be concluded that this performance criteria is not impaired to great effect.

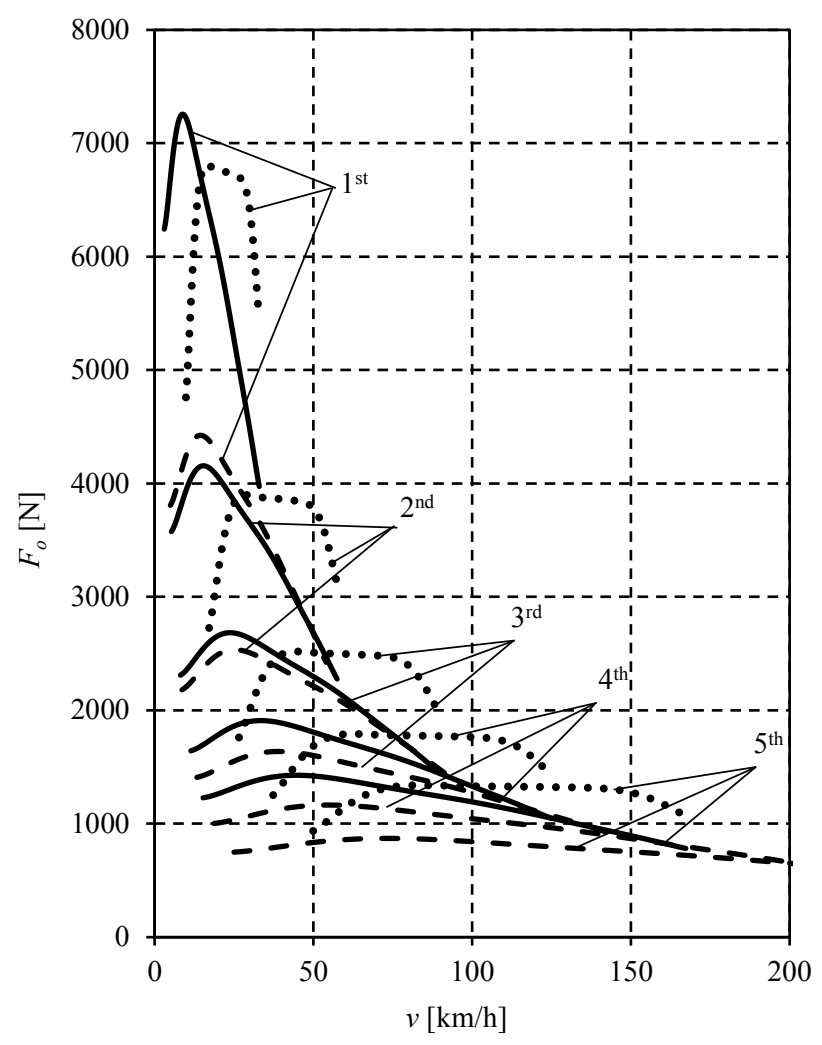

Figure 8 Tractive force $F_{o}$ before (dotted line), after (dashed line) the conversion and with the reduction drive (solid line)

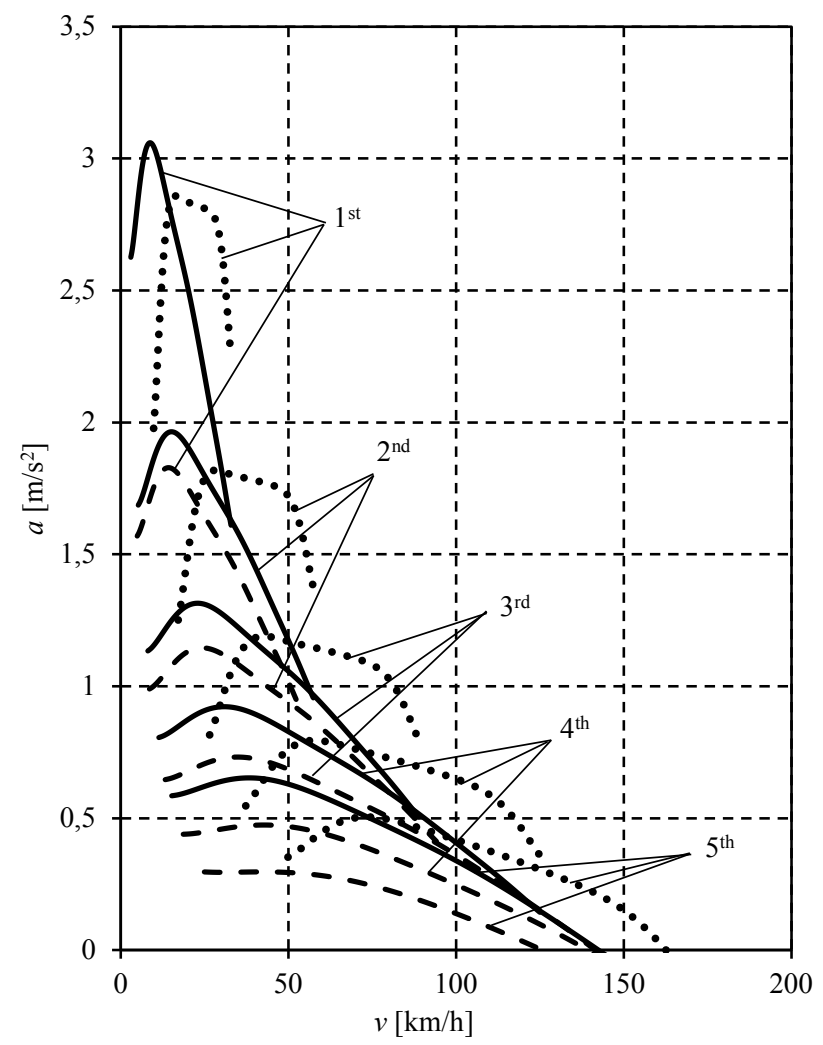

Figure 9 Acceleration $a$ before (dotted line), after (dashed line) the conversion and with the reduction drive (solid line)

Based on previous analyses, it can be concluded that the main reason for deterioration of vehicle performance, beside the lower power of EM, is the higher value of RPM at which this maximum power is achieved. Because of that, the option to install an additional reduction drive 
(at EM output shaft) that will equalise the maximum power RPM value with the ICE is analysed.

Needed gear ratio is $i_{r}=1,64$. Fig. 8 and Fig. 9 show the comparison of traction forces and acceleration for all three variants (ICE, EM, EM with reduction drive).

The results show that by adding the reduction drive, better performance is obtained at lower speeds, in such a way that traction forces and acceleration values are higher than those with ICE, which is important, having in mind the vehicle purpose.

Fig. 10 shows that there are almost no acceleration time improvement, but this is not of great importance again because of the set speed limit.

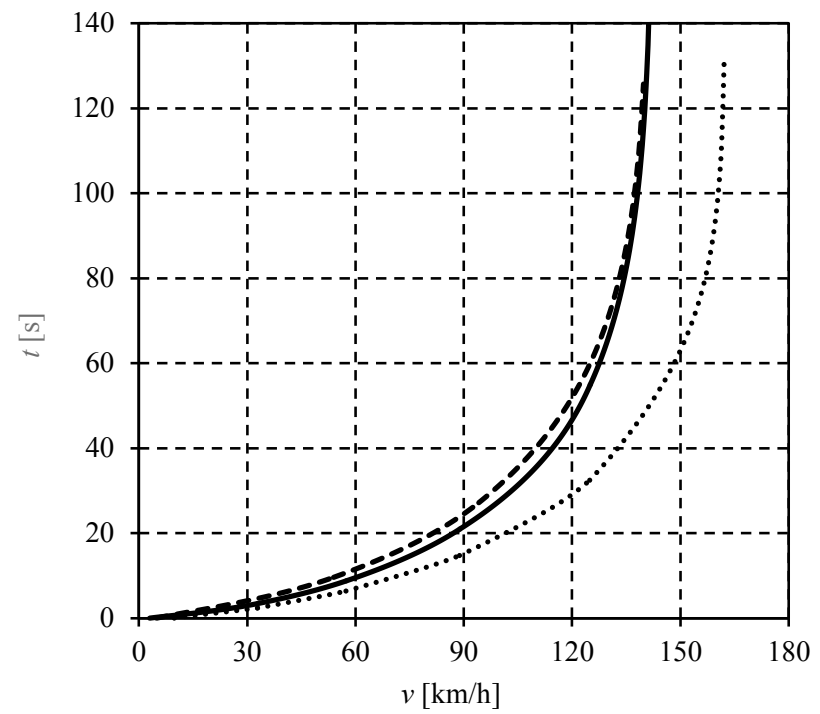

Figure 10 Acceleration time $t$ before (dotted line), after (dashed line) the conversion and with the reduction drive (solid line)

\subsection{Vehicle stability}

In order to check how the conversion affected the vehicle stability, a simulation was run using CarSim 8.02 software. A DLC (dynamic lane change) test shown in Fig. 11 was conducted for both cases (ICE and EM). It consists of a sudden lane change at the speed of $120 \mathrm{~km} / \mathrm{h}$, defined by the coordinates shown in Tab. 4.

Roll angle obtained during the simulation is presented in Fig. 12, showing the little (but sometimes important) difference in favour of the converted vehicle.

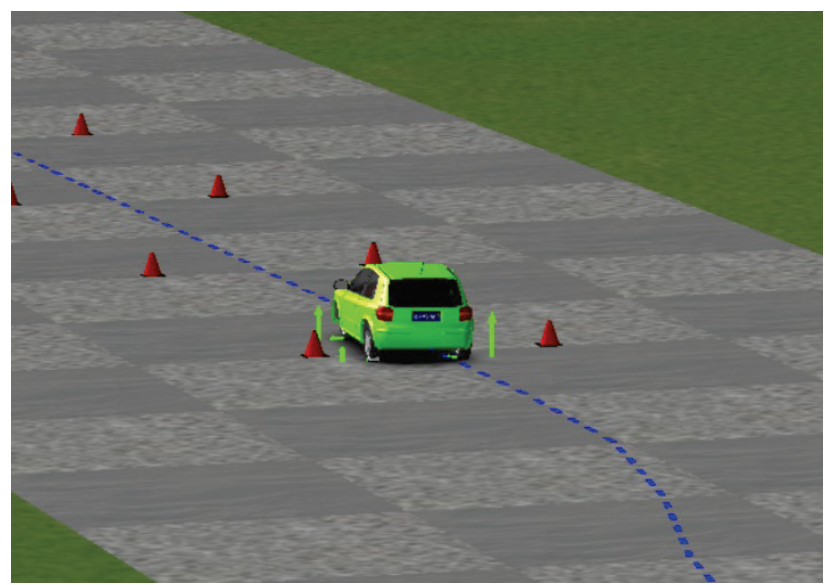

Figure 11 Simulation screenshot

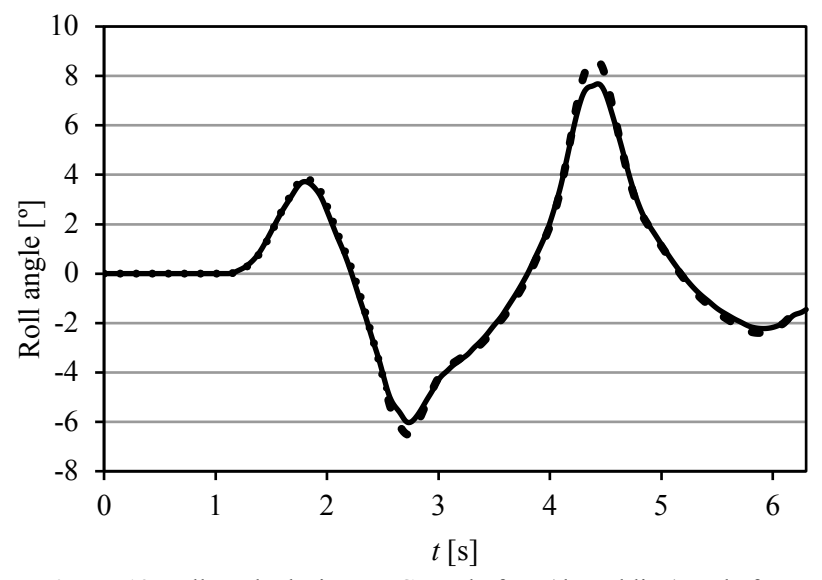

Figure 12 Roll angle during DLC test before (dotted line) and after (solid line) the conversion

\section{Conclusion}

There are many studies outlining the positive effects of electric vehicle usage on emission of gases into atmosphere [17, 18]. That may be the most important factor, but there is more to analyse - economic impact [19], energy consumption [20, 21] and human factors (noise, vibration) [22]. Therefore, it is very important to optimise the electric vehicle itself, and also its usage [23].

The paper shows current concepts for building electric vehicles worldwide, as well as current sources for supplying vehicles with energy. It describes the conversion of an ICE powered vehicle into electric vehicle. The paper gives comparative results of tractive and dynamic characteristics calculation and stability simulation.

It can be concluded that, while making the project of conversion of the vehicle driven by ICE into a pure electric vehicle, it is necessary to consider vehicle exploitation conditions, as well as its purpose for the rest of its lifetime, because it will have a great effect on modification procedure, modification costs and operating costs.

Table 4 DLC test coordinates

\begin{tabular}{|c|c|}
\hline Distance travelled $(\mathrm{m})$ & 0 \\
\hline 0 & 0 \\
\hline 65 & 0,1 \\
\hline 70 & 0,7 \\
\hline 75 & 1,8 \\
\hline 80 & 2,8 \\
\hline 85 & 3,4 \\
\hline 90 & 3,5 \\
\hline 95 & 3,5 \\
\hline 120 & 3,3 \\
\hline 125 & 2,4 \\
\hline 130 & 1,1 \\
\hline 135 & 0,2 \\
\hline 140 & 0 \\
\hline 145 & 0 \\
\hline 150 & \\
\hline & \\
\hline & \\
\hline
\end{tabular}

Vehicle performance greatly depends on the choice of EM. By making a proper one, a satisfactory performance can be achieved. For example, by installing the reduction drive on the motor output shaft to move the maximum power RPM value to that of ICE, higher values of traction 
force and acceleration are obtained. Acceleration graph clearly shows that acceleration values are higher with the EM with reduction drive than with ICE, because of the higher torque values, adding to better vehicle performance.

Presented comparative calculations show that, in case of modifying a conventional vehicle into an electric one, it is extremely important to optimise the parameters related to engine power and torque, as well as the change in vehicle mass, since these three key factors have the effect on final tractive and dynamic characteristics of the modified vehicle. Further analyses show that engine power and torque have greater effect than the change in vehicle mass.

Final recommendation is to stay within the mass parameters of the original vehicle and to use drive units with similar characteristics regarding power and torque. In this way, it is possible to avoid subsequent more complex vehicle modifications in terms of suspension, steering and braking systems.

\section{References}

[1] Hu, H.-W.; Macdonald, C. A.; Trivedi, P.; Anderson, I. C.; Zheng, Y.; Holmes, B.; Bodrossy, L.; Wang, J.-T.; He, J.Z.; Singh, B. K. Effects of Climate Warming and Elevated $\mathrm{CO}_{2}$ on Autotrophic Nitrification and Nitrifiers in Dryland Ecosystems. // Soil Biology and Biochemistry. 92, (2016), pp. 1-15. https://doi.org/10.1016/j.soilbio.2015.09.008

[2] IPCC. Climate change 2013: The physical science basis. Contribution of Working Group I to the Fifth Assessment Reports of the Intergovernmental Panel on Climate Change. Cambridge University Press, Cambridge, 2013.

[3] Ghannoum, O.; Phillips, N. G.; Conroy, J. P.; Smith, R. A.; Attard, R. D.; Woodfield, R.; Logan, B. A.; Lewis, J. D.; Tissue, D. T. Exposure to Preindustrial, Current and Future Atmospheric $\mathrm{CO}_{2}$ and Temperature Differentially Affects Growth and Photosynthesis in Eucalyptus. // Global Change Biology. 16, 1(2010), pp. 303-319. https://doi.org/10.1111/j.1365-2486.2009.02003.x

[4] U.S. Environmental Protection Agency. Inventory of U.S. Greenhouse Gas Emissions and Sinks: 1990-2011. Washington, 2013.

[5] European Environment Agency. Annual European Union Greenhouse Gas Inventory 1990-2013 and Inventory Report 2015. Brussels, 2015.

[6] http://unfccc.int/files/home/application/pdf/paris_agreement .pdf (01.04.2016)

[7] Park, G.; Lee, S.; Jin, S.; Kwak, S. Integrated Modeling and Analysis of Dynamics for Electric Vehicle Powertrains. // Expert Systems with Applications. 41, 5(2014), pp. 25952607. https://doi.org/10.1016/j.eswa.2013.10.007

[8] Ruan, J.; Walker, P.; Zhang, N. A Comparative Study Energy Consumption and Costs of Battery Electric Vehicle Transmissions. // Applied Energy. 165, (2016), pp. 119134. https://doi.org/10.1016/j.apenergy.2015.12.081

[9] Bayindir, K. Ç.; Gözüküçük, M. A.; Teke, A. A Comprehensive Overview of Hybrid Electric Vehicle: Powertrain Configurations, Powertrain Control Techniques and Electronic Control Units. // Energy Conversion and Management. 52, 2(2011), pp. 1305-1313. https://doi.org/10.1016/j.enconman.2010.09.028

[10] Ehsani, M.; Gao, Y.; Emadi, A. Modern Electric, Hybrid Electric, and Fuel Cell Vehicles - Fundamentals, Theory, and Design (2nd ed.). CRC Press, Boca Raton, 2009.

[11] Chan, C. C.; Chau, K. T. Modern Electric Vehicle Technology. Oxford University Press, Oxford, 2001.
[12] Husain, I. Electric and Hybrid Vehicles: Design Fundamentals (2nd ed.). CRC Press, Boca Raton, 2010.

[13] Shenzhen Sinopoly battery Co. SP-LFP100AhA product specification, Doc No. R100-QSI-007.

[14] Stoja d.o.o. ZPM 112L4 product specification.

[15] Warner, J. Battery Management System Controls. // in The Handbook of Lithium-Ion Battery Pack Design. Elsevier, Amsterdam, 2015.

[16] Janković, D.; Todorović, J.; Ivanović, G.; Rakićević, B. Vehicle Dynamics (in Serbian). University of Belgrade, Faculty of Mechanical Engineering, Belgrade, 2001.

[17] Ferrero, E.; Alessandrini, S.; Balanzino, A. Impact of the Electric Vehicles on the Air Pollution from a Highway. // Applied Energy. 169, (2016), pp. 450-459. https://doi.org/10.1016/j.apenergy.2016.01.098

[18] Timmers, V. R. J. H.; Achten, P. A. J. Non-Exhaust PM Emissions from Electric Vehicles. // Atmospheric Environment. 134, (2016), pp. 10-17. https://doi.org/10.1016/j.atmosenv.2016.03.017

[19] Newbery, D.; Strbac, G. What Is Needed for Battery Electric Vehicles to Become Socially Cost Competitive? // Economics of Transportation. 5, (2016), pp. 1-11. https://doi.org/10.1016/j.ecotra.2015.09.002

[20] Galvin, R. Rebound Effects from Speed and Acceleration in Electric and Internal Combustion Engine Cars: An Empirical and Conceptual Investigation. // Applied Energy. 172, (2016), pp. 207-216. https://doi.org/10.1016/j.apenergy.2016.03.120

[21] Agarski, B.; Kljajin, M.; Budak, I.; Tadić, B.; Vukelić, Đ.; Bosak, M.; Hodolić, J. Application of Multi-Criteria Assessment in Evaluation of Motor Vehicles' Environmental Performances. // Technical Gazette. 19, 2(2012), pp. 221-226.

[22] Mićović, A.; Popović, V.; Sedmak, A. Potential for Improvement of Comfort Parameters in Off-Road Vehicles of Serbian Armed Forces. // Technical Gazette. 21, 5(2014), pp. 1009-1016.

[23] Chakraborty, D.; Vaz, W.; Nandi, A. Kr. Optimal Driving During Electric Vehicle Acceleration Using Evolutionary Algorithms. // Applied Soft Computing. 34, (2015), pp. 217-235. https://doi.org/10.1016/j.asoc.2015.04.024

\section{Authors' addresses}

Mirko Gordić, vehicle department manager

AMSS Motor Vehicle Center Ltd

Poenkareova 18, 11120 Belgrade, Serbia

E-mail: gordic@amss-cmv.co.rs

Dragan Stamenković, teaching assistant

University of Belgrade

Faculty of Mechanical Engineering

Kraljice Marije 16, 11120 Belgrade, Serbia

E-mail: dstamenkovic@mas.bg.ac.rs

\section{Vladimir Popović, associate professor}

University of Belgrade

Faculty of Mechanical Engineering

KraljiceMarije 16, 11120Belgrade, Serbia

E-mail: vpopovic@mas.bg.ac.rs

Slavko Muždeka, associate professor

University of Defence in Belgrade

Military Academy

Veljka Lukića Kurjaka 33, 11010 Belgrade, Serbia

E-mail: slavko.muzdeka@gmail.com

\section{Aleksandar Mićović, PhD}

Serbian Armed Forces

Technical Test Centre

Vojvode Stepe 445, 11010 Beograd, Serbia

E-mail: amicovic1@gmail.com 